kirjallisuudella. Se toimii myös sivistyneen kansalaisen kädessä. Kuten hyvä kirja aina, tämäkin ehkä herättää enemmän kysymyksiä kuin antaa suoria vastauksia.

Kirjan keskeinen teoreettinen kehys perustuu valtiososialismin aikana syntyneen keskustaperiferia-dynamiikkaan, minkä opit vaikuttavat edelleen poliittisten johtajien toimissa. Vaikka tämä viitekehys osoittautuu mitä mainioimmaksi tämän kirjan osalta, uskallan kuitenkin väittää, että se kuuluu pian historiaan. Kilpailua ja taloutta käsittelevässä luvussa Katalin Miklossy toteaa, että itäisen Euroopan maista tuli 1990-luvulla nopeasti yksityistämisen yhteydessä "tytäryhtiötalouksia" (s. 63). Termi on osuva - ja kuten tiedetään - tytäryhtiöiden tuottamat voitot valuvat helposti emoyhtiölle eikä verojakaan tarvitse maksaa joko yhtiön sisäisten järjestelyjen tai sallivan lainsäädännön ansiosta. Keskusta-periferia-dynamiikka tämän kirjan yhteydessä koskee kuitenkin lähinnä valtioiden välisiä suhteita, kun taas tytäryhtiötalous viittaa yritysten välisiin suhteisiin.

Läpi lukujen toistuva teema kirjassa on myös markkinavoimien kasvava ja kyseenalaistamaton ylivalta itäisessä Euroopassa. Sama pätee tosin muuhunkin Eurooppaan ja maailmaan. Näin kirja osoittaa hienosti, että itäinen Eurooppa painii samojen ongelmien kanssa kuin läntinen Eurooppa ja Pohjois-Amerikka. Demokratian karikot, ne syvät syyt, joita populismin väitettiin vain heijastavan, näyttäytyvät enemmänkin globaaleina ongelmina kuin yksistään itäisen Euroopan ongelmina. Kaikki viittaa siihen, että seuraava katsaus itäiseen Eurooppaan saattaakin keskittyä talouden keskusta-periferiadynamiikkaan. Ehdotankin, että seuraavissa pohdinnoissa keskustan ja periferian välillä vallitsevaa dynamiikkaa käsiteltäisiin suhteessa politiikkaan, lakiin ja valtioon eikä enää vain itäistä Eurooppaa varten kehitellystä teoriasta käsin, vaan globaaleja kehityksiä, demokratiaa käsitteenä, markkinataloutta taloudellisena järjestelmänä ja oikeusvaltiota lain teoriana valottavista viitekehyksistä käsin. Lopputulemana voikin sanoa, että kirja palauttaa lukijan itäisen Euroopan kautta takaisin politiikan peruskysymysten äärelle: pohdintoihin yksilön, valtion ja kollektiivisen toiminnan mahdollisuuksista, oikeuksista ja rajoista.

\section{Jaakko Turunen}

\title{
Venäjä-tietoutta sopivina suupaloina
}

\section{Pekka Hakala \& Juha Metso: Putinlandia: tarinoita Venäjältü.. Helsinki: Otava, 2018. 264 s. ISBN: 9789511329060.}

Pekka Hakala on Helsingin Sanomien Venäjään erikoistunut toimittaja ja entinen Moskovankirjeenvaihtaja, jonka suhde maahan on syvä ja moniulotteinen. Juha Metso puolestaan on valokuvaaja, joka on käynyt kuvausmatkoilla Venäjällä jo useamman vuosikymmenen ajan. Putinlandia on heidän yhteisteoksensa.

Suomessa julkaistaan vuosittain runsaasti Venäjä-aiheista kirjallisuutta. Suurin osa tästä on vakavamielistä Venäjä-asiaa, joka ruotii maan yhteiskuntaa, politiikkaa tai taloutta tutkimusten valossa, eikä näin ole tavalliselle lukijalle välttämättä kovin helposti lähestyttävää. Kevyempää Venäjä-tietokirjallisuutta ilmestyy yhä yllättävän vähän. Putinlandia täyttää juuri tätä aukkoa.

Kuten kirjan nimi jo vihjaa, se ei suhtaudu tarkastelukohteeseensa synkeän vakavamielisesti, vaan kutsuu lukijan ihmettelemään Venäjää.
Toki kirja on paikoin ja tarpeen mukaan hyvinkin vakava, mutta usein alta kumpuaa hieman humoristinen pohjavire ja lempeys itäistä naapuriamme kohtaan. Teos tarjoaa tekstin ja kuvan muodossa välähdyksiä Venäjästä. Mikään muu kuin välähdykset eivät olisikaan mahdollista, kun ottaa huomioon kirjan koon suhteessa käsiteltävän aiheen laajuuteen. Kirjan kahdentoista luvun aikana lukija nimittäin kuljetetaan halki Venäjän niin maantieteellisesti kuin ajallisesti. Lukujen sisällä hypitään sujuvasti 1980-luvulta nykypäivään ja 1990-luvulle ja taas takaisin. Kuulostaa ehkä sekavalta, mutta kirja ei suinkaan ole sitä, sillä Pekka Hakala on oiva opas, joka pitää huolta siitä, että lukija pysyy mukana.

Juuri tästä syystä Putinlandiaa on ilo lukea. Hakalan asiantuntemus aiheesta huokuu läpi joka lauseesta ja huomaa, että hän on toimittajana tottunut selittämään Venäjän tapahtumia auki niistä vähemmän tietäville. Hän tietää millä tahdilla uutta tietoa tulee annostella ja miten herättää lukijan kiinnostus. Useampaan otteeseen hän 
toteaa palaavansa asiaan myöhemmin juurikin sillä hetkellä, kun lukijan päässä alkaa risteillä liikaa ajatuksia.

Putinlandian nimi johtaa myös harhaan. Sen keskushenkilö on Vladimir Putin vain näennäisesti. Kremlin valtapolitiikkaa, Putinia ja hänen sisäpiiriään sivutaan toki monessa kohtaa, mutta kirjan todellisia päähenkilöitä ovat tavalliset ihmiset. Hakala (ja myös Metso kuvissaan) nauraa venäläisille ja näiden kanssa - mutta samalla myös itselleen. Hän päästää tavallisen venäläisen usein ääneen kertomaan, millaista Venäjällä on ja sitä kautta paljastuu koko spektri absurdista iloiseen, surullisesta käsittämättömään. Venäläisten suulla Hakala tekee myös tarkkoja havaintoja meistä suomalaisista. Ihmetys naapurista on molemminpuolista. Syntyy keskustelu, joka on sävyltään paljon lämpimämpi kuin ensinäkemältä vaikuttaa. Tämä on kirjan parasta antia.

Hakala on hyvin uskottava ja mukaansatempaava kertoja. Kun hän puhuu rupattelevaan sävyyn Boris Nemtsovin murhasta ja kertoo, että se tapahtui muutaman korttelin päässä sieltä, missä hän silloin oli, tai kuvaa kokemuksiaan Itä-Ukrainan sotatoimialueella ja Tšetšeniassa, on vaikea olla uskomatta hänen selontekojaan. Otsikot ja uutiset saavat inhimillisen kosketuspinnan ja paikoin tuntuu, kuin lukija istuisi oluella Hakalan kanssa tämän muistellessa matkojaan.

Hakalan erikoisalaa on kremnologia - Venäjän vallan ytimessä tapahtuvat asiat. Kirjan näihin teemoihin liittyvät luvut ovat ehkä sen mielenkiintoisinta antia. Asiantuntijalle ne tarjoavat vähän uutta, mutta kiinnostavinta on se, miten Hakalan onnistuu kansantajuistaa Venäjän vaikeita valtasuhteita, -rakenteita ja sitä, miten ne ovat muodostuneet. Ihan erityisesti on nostettava esiin Tšetšeniaa käsittelevä luku, joka on niin hyvä yleisesitys alueen tilanteesta, että sen soisi olevan osa lukemistoa aihetta käsittelevillä lukion tai yläkoulun tunneilla.

Jokaista lukua tahdittavat Juha Metson upeat kuvat, joita hän on ottanut vuosien varrella eri yhteyksissä Venäjällä. Ne maalaavat kuvaa Venäjästä, joka on yhtä aikaa tuttu ja vieras. Osa kuvista on sellaisia, joita lukija odottaakin näkevänsä; toiset taas jotain aivan muuta. Metson kuvien kautta saa aavistuksen maan moninaisuudesta, kurkistuksen kaoottiseen mysteeriin nimeltä Venäjä.
Putinlandian suurin puute on kuvan ja tekstin suhteessa. Kuten jo todettua Hakalan esseemäiset tekstit ja Metson valokuvakokoelma ovat molemmat kiistatta erinomaisia, mutta niiden ongelma on, etteivät ne keskustele keskenään niin hyvin kuin voisivat. Useampaan otteeseen joutuu pohtimaan, miten Metson upea kuva liittyy Hakalan tekstiin. Liian usein vastaus on, ettei se suoranaisesti liitykään. Tämä luo irrallisuuden tuntua, jota korostaa se, että kaikkien kuvien selitteet on koottu vain kirjan loppuun, josta ne joutuu erikseen tarkistamaan.

Kuvan ja tekstin keskusteluyhteyden epäsuhta korostuu kirjan loppupuolen luvussa Paluu Petšora-joelle, jossa puolestaan kuva ja teksti kulkevat todella hienosti rinta rinnan. Syykin on selvä: Metso ja Hakala matkustivat alueelle yhdessä. On hieman harmi, ettei kuvan ja tekstin välinen dialogi ole tällaista läpi koko kirjan.

Hetkittäin Hakala tuntuu myös hukkaavan punaisen langan. Tuntuu kuin hän ei olisi osannut päättää, onko hänen tarkoituksensa esitellä Putinin henkilöhistoriaa, nousua valtaan ja vallankahvassa pysymistä vai sittenkin keskittyä siihen, mitä nyky-Venäjällä tapahtuu ja millaisia ovat Putinlandian asukkaat. Itse luvut ovat tiiviitä, selvästi rajattuja kokonaisuuksia, joista ei sovi valittaa, mutta joitain valituista aihepiireistä olisi sen sijaan voinut miettiä vielä tarkemmin. Tämä saattaa tosin olla tietoinen valinta, jonka tarkoitus on vain korostaa sitä tosiasiaa, että Venäjä on valtava, kaoottinen kokonaisuus, jonka sisällä on loputtomasti uusia kerroksia. Jos tämä mielikuva on ollut tarkoituksena, siinä tekijät ovat onnistuneet.

Edellä mainituista pienistä puutteista huolimatta Putinlandia on erittäin kiinnostava teos, joka tarjoaa kurkistuksen siihen Venäjään, joka ei usein lehtijuttujen otsikoissa, tv-inserteissä tai artikkeleissa tule esille. Se on erinomainen teos Venäjä-ummikolle tai Venäjästä jo vähän tietäville. Asiantuntijalle kirja ei tarjoa juuri uutta, mutta uskallan väittää, että Hakalan omaehtoinen, anekdoottimainen tyyli viettelee mukaansa kyllä melkein lukijan kuin lukijan.

Aleksi Kuutio 